\title{
Laba dan Arus Kas dalam Memprediksi Laba dan Arus Kas Masa Mendatang dan Pola Harga Saham
}

\author{
Junaidi \\ Program Studi Akuntansi Universitas Teknologi Yogyakarta \\ Л. Prof. Dr. Soepomo, S.H. No. 21 Janturan, Umbulharjo, Yogyakarta 55165 \\ Email: masjoen@uty.ac.id
}

\begin{abstract}
ABSTRAK
Penelitian ini bertujuan untuk menguji secara empiris kemampuan laba dan arus kas dalam memprediksi laba masa depan dan arus kas dan pola harga saham. Sampel penelitian diambil menggunakan purposive sampling perusahaan-perusahaan manufaktur yang terdaftar di Bursa Efek Indonesia. Hasil analisis data menggunakan Autoregressive Integrated Moving Average (ARIMA) model menunjukkan bahwa empat dari lima hipotesis yang diajukan terbukti. Hal ini berarti bahwa laba dapat memprediksi laba masa depan dan pola pergerakan harga saham, harga saham sekarang dapat memprediksi harga saham mendatang dan arus kas runtun waktu dapat memprediksi arus kas mendatang. Namun, hipotesis kelima yang menyatakan bahwa arus kas runtun waktu dapat memprediksi pola pergerakan harga saham tidak terbukti.
\end{abstract}

Kata kunci: Laba, arus kas, harga saham, Model ARIMA, prediksi.

\begin{abstract}
This study aims to test empirically the ability of earnings and cash flows in predicting future earnings and cash flows and stock prices fluctuation pattern. The samples of the research are drawn by using purposive sampling from manufacturing companies listed in Indonesian Stock Exchange. The results of data analysis using Autoregressive Integrated Moving Average (ARIMA) model show that four of five hypothesis are supported. It means that earnings are able to predict future earning and stock price fluctuation pattern, current stock prices can predict future earning price and the series of cash flows can predict future cash flows. However, the fifth hypothesis stated that cash flows can predict stock prices pattern cannot be proved.
\end{abstract}

Keywords: Earnings, cash flows, stock prices, ARIMA model, prediction.

\section{PENDAHULUAN}

Penelitian ini bertujuan untuk membuktikan secara empiris kemampuan laba dan arus kas dalam meramal laba dan arus kas masa depan dan pola harga saham. Telah banyak penelitian yang dilakukan baik menyangkut kandungan informasi laba maupun arus kas. Meskipun demikian penelitian di Indonesia yang menyangkut pengujian laba dan arus kas untuk meramal laba dan arus kas masa depan dan pola harga saham belum banyak dilakukan. Penelitian-penelitian kandungan informasi laba telah menunjukkan hasil yang relatif konsisten, namun penelitian kandungan informasi arus kas masih menunjukkan hasil yang belum konklusif.

Terdapat beberapa kontribusi yang diharapkan dari penelitian ini. Pertama, penelitian ini diharapkan dapat menyediakan kontribusi berupa bukti empirik yang belum disediakan oleh peneliti- an sebelumnya, yakni laba bermanfaat dalam memprediksi laba di masa yang akan datang. Kedua, laba bermanfaat dalam memprediksi pola harga saham. Ketiga, arus kas bermanfaat dalam memprediksi arus kas di masa yang akan datang. Keempat arus kas bermanfaat dalam memprediksi pola harga saham. Kelima penelitian ini diharapkan memberikan kontribusi berupa bukti empirik apakah ada faktor lain yang dipertimbangkan dalam meramal laba, arus kas dan pola harga saham.

Menurut teori penilaian (valuation theory) yang dikembangkan dalam manajemen keuangan untuk organisasi pencari laba, nilai perusahaan yang tercermin dalam harga sahamnya merupakan nilai tunai dari dividen masa mendatang (Sugiri 2003). Gordon (1962) sebagaimana dikutip Sugiri (2003), misalnya, mengembangkan dua model penilaian: 1) model laba (earnings model); dan 2) model dividen (dividend model). Model laba 
(dividen) menjelaskan bahwa nilai perusahaan merupakan nilai tunai dari laba (dividen) masa mendatang. Kedua model ini tidak dapat menjelaskan nilai saham seandainya perusahaan dalam masa yang panjang tidak membagi dividen. Brigham dan Gapenski (1991) sebagaimana dikutip Sugiri (2003) menyatakan bahwa model penilaian yang lebih umum menyatakan bahwa nilai perusahaan merupakan nilai tunai dari arus kas masa mendatang, sehingga walaupun perusahaan tidak membagi laba dalam bentuk dividen, penentuan nilai perusahaan dapat dilakukan.

Sesuai dengan rerangka konseptual atau rerangka dasar penyusunan dan penyajian laporan keuangan, Ikatan Akuntan Indonesia (PSAK No.1 tahun 2009) menyatakan bahwa informasi kinerja perusahaan, terutama profitabilitasnya bermanfaat untuk memprediksi kapasitas perusahaan dalam menghasilkan arus kas dari sumber daya yang ada (paragraf 17). Laporan arus kas adalah laporan keuangan yang menunjukkan arus kas masuk dan keluar kas atau setara kas selama periode tertentu suatu perusahaan (Hendriksen 1991). Laporan arus kas diklasifikasikan menurut aktivitas operasi, aktivitas investasi, dan aktivitas pendanaan.

Menurut PSAK No. 2 paragraf 03, kegunaan informasi arus kas adalah (1) jika digunakan dalam kaitannya dengan informasi keuangan lainnya, laporan arus kas dapat memberikan informasi yang memungkinkan bagi para pemakainya untuk mengevaluasi perubahan dalam aktiva bersih perusahaan, struktur keuangan, dan kemampuan untuk mempengaruhi jumlah serta waktu arus kas dalam rangka adaptasi dengan perubahaan keadaan dan peluang, (2) menilai perusahaan dalam menghasilkan kas dan setara kas serta memungkinkan pemakainya mengembangkan modal untuk menilai dan membandingkan nilai arus kas sekarang dengan nilai arus kas masa depan dari berbagai perusahaan, (3) meningkatkan daya banding pelaporan kinerja operasi dari berbagai perusahaan, karena dapat meniadakan pengaruh penggunaan perlakuan akuntansi yang berbeda terhadap peristiwa dan transaksi yang sama. Manfaat dari laporan arus kas adalah untuk: (1) memprediksi tanda-tanda bahaya dalam bidang keuangan, (2) mengetahui resiko, ukuran, dan penjadwalan keputusan kredit, (3) memprediksi rating kredit, (4) menilai kinerja perusahaan, dan (5) menyajikan informasi tambahan di pasar modal (Bowen et al. 1986).

Penelitian mengenai kandungan informasi yang terdapat dalam laba dimulai oleh Ball dan Brown (1968). Dari penelitian tersebut mereka menemukan hubungan yang signifikan antara unexpected earnings dengan abnormal return.
Penelitian ini kemudian diikuti oleh Beaver (1968), Lipe (1986), Bernard dan Stober (1989). Ball dan Watts (1972) mencoba mengungkap potensi prediksi laba dengan alat statistik, run test dan serial correlation. Hasil penelitiannya menunjukkan bahwa perubahan laba ternyata mempunyai model yang acak (random walk). Dengan sifat laba yang time series, dan pola perubahan yang bersifat random, menunjukkan bahwa laba memiliki potensi sebagai prediktor. Fairfield et al. (1996) meneliti apakah laba yang lebih terinci lebih baik daripada klasifikasi laba yang relatif kurang terinci daalam kemampuannya memprediksi ROE setahun yang akan datang. Fairfield et al. (1996) menemukan bahwa special items menyediakan infromasi tentang laba bersih (ROE) masa datang dan seharusnya tidak diabaikan dalam memprediksi ROE, dan pos-pos luar biasa dan operasi yang tidak dilanjutkan dapat diabaikan dalam menaksir profitabilitas masa mendatang. Beberapa penelitian di Indonesia tentang manfaat laba dalam memprediksi laba telah dilakukan oleh beberapa peneliti antara lain: Parawiyati (1996), Sunariyah (1996), Isgiyarta (1997), Parawiyati dan Baridwan (1998), Werdiningsih (2000), Madjid (2002), Kholidiyah (2002), Andayani et al. (2011), dan Junaidi (2011).

Bowen et al. (1986) melakukan penelitian apakah arus kas merupakan prediktor yang lebih baik daripada laba dalam memprediksi arus kas masa yang akan datang. Penelitian ini didasarkan pada sample 342 perusahaan dengan menggunakan model random walk. Hasil analisis menunjukkan bahwa arus kas merupakan prediktor yang lebih baik daripada laba dalam memprediksi arus kas sampai dengan dua tahun mendatang. Ismail dan Kim (1989) melakukan penelitian untuk menguji apakah arus kas mempunyai tambahan informasi di luar laba akrual dalam konteks untuk menjelaskan risiko pasar. Pengujian dengan model regresi dengan periode pengamatan tahun 1966-1985. Hasil analisis menunjukkan bahwa arus kas secara signifikan meningkatkan kemampuan dalam menjelaskan risiko pasar.

Supriyadi (1999) meneliti hubungan antara informasi akuntansi dan arus kas masa yang akan datang. Supriyadi menggunakan model regresi linier yang parameter-parameternya ditaksir dengan menggunakan data semesteran selama periode 1990-1997. Supriyadi (1999) menemukan bahwa data aliran kas menyediakan informasi yang lebih baik untuk menilai aliran kas perusahaan masa depan. Hal lain yang ditemukan adalah bahwa aliran kas yang digunakan di penelitian ini untuk memprediksi aliran kas masa depan tidak lebih baik dibandingkan dengan 
model kombinasi laba dan aliran kas. Cheng et al. (1996) sebagaimana dikutip oleh Kusuma (2003) menguji nilai tambah kandungan informasi laba dan arus kas operasi dengan menggunakan model linier dan nonlinier. Penelitian ini berhasil memberikan bukti empiris tentang adanya nilai tambah kandungan informasi laba dan arus kas operasi.

Parawiyati dan Baridwan (1998) mengukur kemampuan laba dan arus kas untuk memprediksi laba dan arus kas. Parawiyati dan Baridwan (1998) menemukan bahwa baik laba dan aliran kas merupakan prediktor yang signifikan untuk memprediksi laba dan aliran kas masa depan untuk jangka waktu satu tahun ke depan. Kemudian, pada penelitian Utami (1999) diperoleh hasil yang menyatakan kemampuan arus kas untuk memprediksi arus kas mendatang, sedangkan dalam jangka panjang kemampuan data arus kas setara dengan laba.

Penelitian Kusuma (2003) menyimpulkan bahwa laba tidak mempunyai nilai tambah kandungan informasi di luar informasi yang diberikan oleh arus kas operasi ketika laba bersifat permanen. Hal ini mempunyai implikasi bahwa kebutuhan informasi dapat dipenuhi oleh informasi arus kas operasi. Implikasi lainnya adalah kemungkinan bahwa informasi laba merupakan bagian dari infromasi arus kas operasi. Temuan selanjutnya, ketika laba bersifat permanen, arus kas operasi mempunyai nilai tambah kandungan informasi di luar informasi yang diberikan oleh laba. Kemudian arus kas operasi mempunyai nilai tambah kandungan informasi ketika laba mengandung komponen transitori yang tinggi.

Kemudian pengujian hubungan arus kas dengan harga saham telah dilakukan oleh Rayburn (1986). Rayburn (1986) menemukan bahwa laba yang dipisahkan ke dalam komponen kas dari operasi dan total accrual mempunyai tambahan kandungan informasi dan terdapat hubungan antara arus kas operasi dengan return saham. Bernard dan Stober (1989) yang menemukan adanya reaksi harga saham yang sangat tinggi sekali terhadap pengumuman arus kas. Cheng , Liu dan Schaeler sebagaimana dikutip oleh Hermawan dan Hadyansah (2002) menyatakan bahwa arus kas memiliki pengaruh yang signifikan terhadap return meskipun variable laba dikontrol. Mereka juga menemukan bahwa pengaruh arus kas yang diperoleh melalui estimasi terhadap return saham tidak berbeda secara signifikan dengan pengaruh arus kas yang disajikan dalam laporan arus kas. Alaraini dan Stephens (1999) menemukan adanya hubungan antara informasi arus kas dan penilaian sekuritas.

Pada penelitian yang dilakukan Parawiyati dan Baridwan (1998), Supriyadi (1999) dan Utami
(1999), terdapat beberapa kelemahan, yaitu tentang data yang digunakan. Selain terdapat kelemahan dalam data sample penelitian-penelitian tersebut belum sampai pada pengujian reaksi pasar. Penelitian Supriyadi (1999) menggunakan data 1990-1997, Parawiyati dan Baridwan (1998) menggunakan data arus kas tahun 1984-1994 dan Utami (1999) menggunakan data arus kas tahun 1994-1998. Padahal laporan arus kas baru diwajibkan mulai tahun buku 1995. Pada penelitian Parawiyati dan Baridwan (1998) data arus kas dalam diperoleh dengan pengolahan data (data manipulation) dari laporan laba-rugi dan perbandingan dua Neraca. Data hasil pengolahan tersebut tidak mencerminkan informasi tentang arus kas sesungguhnya yang langsung diperoleh atau dibaca oleh para pengguna dari laporan arus kas, serta kesalahan pengukuran arus kas juga sangat potensial terjadi. Kelemahan yang sama juga dapat dilihat dalam Utami (1999) yang menggunakan data selama periode 1994-1998, yang dua tahun pertama dari perioda tersebut menggunakan data manipulasi untuk mengukur arus kas.

Terdapat beberapa kontribusi yang diharapkan dari penelitian ini. Pertama, penelitian ini diharapkan dapat menyediakan kontribusi berupa bukti empirik yang belum disediakan oleh penelitian sebelumnya, yakni laba bermanfaat dalam memprediksi laba di masa yang akan datang. Kedua, laba bermanfaat dalam memprediksi pola harga saham. Ketiga, arus kas bermanfaat dalam memprediksi arus kas di masa yang akan datang. Keempat arus kas bermanfaat dalam memprediksi pola harga saham. Kelima penelitian ini diharapkan memberikan kontribusi berupa bukti empirik apakah ada faktor lain yang dipertimbangkan dalam meramal laba, arus kas dan pola harga saham.

\section{TINJAUAN PUSTAKA DAN HIPOTESIS}

\section{Nilai Suatu Perusahaan}

Ball dan Brown (1968) berusaha menguji hubungan antara data akuntansi (accounting income numbers), dengan value of the firm. Data akuntansi dijadikan sebagai kriteria prediksi dalam keputusan investasi sebagaimana direfleksikan dalam harga sekuritas di pasar modal. Menurut teori penilaian (valuation theory) yang dikembangkan dalam manajemen keuangan untuk organisasi pencari laba, nilai perusahaan yang tercermin dalam harga sahamnya merupakan nilai tunai dari dividen masa mendatang (Sugiri 2003). Laba lebih baik daripada arus kas baik untuk memprediksi laba maupun untuk 
memprediksi arus kas masa mendatang dan laba menyediakan kemampuan prediksi inkremental terhadap arus kas untuk memprediksi arus kas masa mendatang (Parawiyati dan Baridwan 1998).

\section{Arus kas}

Laporan arus kas adalah laporan yang menunjukkan aliran kas masuk dan arus kas keluar dari aktivitas operasi (operating), investasi (investing), dan pendanaan (financing) suatu badan usaha selama satu periode (Kieso et al. 2011). SFAS No 95:1987 sebagaimana dikutip oleh Baridwan (2004) menyatakan bahawa tujuan utama laporan arus kas adalah menyediakan informasi tentang kas yang diterima dan dibayarkan suatu unit bisnis selama satu periode. Tujuan kedua adalah menyediakan informasi mengenai aktivitas operasi, investasi dan pendanaan suatu unit bisnis selama satu periode. Laporan arus kas melaporkan penerimaan kas, pembayaran kas, dan perubahan kas bersih yang diakibatkan dari aktivitas operasi, investasi dan pendanaan suatu badan usaha selama satu periode dalam format yang mencakup kas awal dan akhir neraca.

\section{Peramalan Laba}

Pada tahun 1980-an riset akuntansi sudah mulai berkonsentrasi menggunakan peramalan laba sebagai proksi untuk pasar modal (Brown, 1993). Foster (1977a) mengevaluasi model-model ekspektasi laba, dengan menguji kemampuan model tersebut dalam meramalkan laba, kemudian menghubungkan pergerakan harga saham dengan kesalahan model yang digunakan untuk memprediksi. Patell (1976a) menguji kandungan informasi ramalan laba yang dibuat manajemen. Beberapa penelitian lain seperti Copeland dan Marioni (1972), Hagerman dan Ruland (1977) dan McDonald, Lorek, dan Patz (1976) menyimpulkan bahwa ramalan yang dibuat oleh manajemen itu ternyata akurat setelah dibuktikan dengan realisasi ramalannya (Kholidiah, 2002).

Finger (1994) menguji relevansi nilai dari laba yang diukur berdasarkan kemampuannya untuk meramal baik laba masa depan maupun aliran kas (Febriyanti 2004). Laba merupakan prediktor yang signifikan bagi laba itu sendiri selama periode satu tahun tapi tidak untuk empat sampai delapan tahun. Laba juga mempunyai kemampuan prediktor bagi aliran kas untuk beberapa perusahaan.

Di Indonesia penelitian mengenai peramalan laba telah dilakukan oleh beberapa peneliti. Isgiyarta (1997) mereplikasi Fairfiled et al. (1996) dengan sedikit memodifikasi model klasifikasi sepuluh komponen. Isgiyarta memprediksi bahwa laba rincian lebih spesifik menyediakan tambahan perbaikan peramalan laba bersih di atas model laba rincian kurang spesifik. Sunariyah (1996) yang menguji ramalan laba di prospectus pada awal penawaran umum di pasar modal Indonesia, menyatakan bahwa ramalan laba di Indonesia belum jelas. Hal ini disebabkan banyaknya investor-investor Indonesia yang menanamkan modal dengan emosional. Penelitian ini dilanjutkan oleh Madjid (2002) yang menyelidiki hubungan ketepatan ramalan laba dengan return saham di pasar perdana dan menemukan bahwa initial return tidak dipengaruhi ketepatan ramalan laba yang disebabkan oleh kondisi pasar modal Indonesia masih terjadi asimetri informasi. Parawiyati dan Baridwan (1998) dan Supriyadi (1999) menemukan bahwa laba (agregat) historis merupakan prediktor yang baik untuk arus kas dan prediktor yang baik untuk laba.

Kholidiah (2002) menyatakan bahwa metode regresi ternyata lebih unggul bila dibandingkan dengan model naïve, model ARIMA lebih akurat dibandingkan dengan regresi sederhana. Temuan selanjutnya menunjukkan bahwa model ARIMA merupakan model yang paling akurat dibandingkan dengan model naïve maupun regresi. Andayani et al. (2011) menunjukkan bahwa laba masa lalu dapat digunakan untuk mengestimasi laba masa depan. Junaidi (2011) menunjukkan bahwa laba memiliki kemampuan memprediksi laba dan pola harga saham di masa yang akan datang. Selanjutnya hipotesis yang diungkapkan sebagai berikut:

$\mathrm{H}_{\mathrm{A}}{ }^{1}$ : Terdapat kemampuan laba time series dalam memprediksi laba mendatang.

$\mathrm{H}_{\mathrm{A}}{ }^{2}$ : Terdapat kemampuan harga saham dalam memprediksi harga saham mendatang.

$\mathrm{H}_{\mathrm{A}}{ }^{3}$ : Terdapat kemampuan laba time series dalam memprediksi pola harga saham.

\section{Peramalan Arus Kas}

SFAC No. 2 menyatakan bahwa salah satu karakteristik kualitatif yang harus dimiliki informasi akuntansi agar tujuan pelaporan keuangan dapat tercapai adalah kemampuan laporan keuangan sebagai alat prediksi (FASB 1980). Menurut IAI (2009), informasi arus kas historis berguna sebagai indikator dari jumlah, waktu, dan kepastian arus kas di masa mendatang (PSAK No.2). FSAB (1987) menyatakan bahwa informasi dalam laporan arus kas diharapkan membantu para pemakai laporan keuangan, antara lain, untuk menaksir kemampuan perusahaan untuk menghasilkan arus kas di masa mendatang. 
Menurut teori penilaian (valuation theory) yang dikembangkan dalam manajemen keuangan untuk organisasi pencari laba, nilai perusahaan yang tercermin dalam harga sahamnya merupakan nilai tunai dari dividen masa mendatang (Sugiri 2003). Brigham dan Gapenski (1991) sebagaimana dikutip Sugiri (2003) menyatakan bahwa model penilaian yang lebih umum menyatakan bahwa nilai perusahaan merupakan nilai tunai dari arus kas masa mendatang, sehingga walaupun perusahaan tidak membagi laba dalam bentuk dividen, penentuan nilai perusahaan dapat dilakukan.

Bowen et al. (1986) menyatakan bahwa arus kas merupakan predictor yang lebih baik daripada laba dalam memprediksi arus kas dampai dengan dua tahun mendatang. Baridwan (1997) menyatakan bahwa informasi arus kas memiliki nilai tambah dan, oleh karena itu, keputusan IAI untuk mengeluarkan PSAK No.2 adalah sudah sesuai. Supriyadi (1999) menemukan bukti empiris bahwa arus kas menyediakan informasi ekstra di atas laba dalam memprediksi arus kas periode yang akan datang. Parawiyati dan Baridwan (1998) menemukan bahwa baik laba dan aliran kas merupakan predictor yang signifikan untuk memprediksi laba dan aliran kas masa depan untuk jangka waktu satu tahun ke depan. Penelitian Utami (1999) juga mendapat kesimpulan bahwa arus kas mampu memprediksi arus kas periode mendatang, sedangkan untuk jangka panjang kemampuan data arus kas setara dengan laba.

Rayburn (1986) menemukan bahwa laba yang dipisahkan ke dalam komponen kas dari operasi dan total accrual mempunyai tambahan kandungan informasi dan terdapat hubungan antara arus kas operasi dengan return saham. Bernard dan Stober (1989) yang menemukan adanya reaksi harga saham yang sangat tinggi sekali terhadap pengumuman arus kas. Cheng , Liu dan Schaeler sebagaimana dikutip oleh Hermawan dan Hadyansah (2002) menyatakan bahwa arus kas memiliki pengaruh yang signifikan terhadap return meskipun variable laba dikontrol. Mereka juga menemukan bahwa pengaruh arus kas yang diperoleh melalui estimasi terhadap return saham tidak berbeda secara signifikan dengan pengaruh arus kas yang disajikan dalam laporan arus kas. Berdasarkan konsepkonsep dan temuan penelitian-penelitian sebelumnya, maka diungkapkan beberapa hitotesis penelitian, yaitu:

$\mathrm{H}_{A}{ }^{4}$ : Terdapat kemampuan arus kas time series dalam memprediksi arus kas mendatang.

$\mathrm{H}_{A^{5}}$ : Terdapat kemampuan arus kas time series dalam memprediksi pola harga saham.

\section{METODA PENELITIAN}

\section{Data dan Sampel}

Data diambil dari pusat data pasar modal UGM tahun 1999-2010. Sampel yang akan digunakan mengikuti kriteria, yaitu: data laba dan arus kas perusahaan-perusahaan manufaktur yang listed di BEI tahun 1999-2010. Disamping data laporan keuangan, juga diperlukan data harga saham harian (closing price) perusahaan sampel periode 1999-2010.

\section{Pengujian hipotesis pertama}

Pengujian hipotesis pertama dilakukan dengan metode ARIMA. Menurut Kuncoro (2001), parameter-parameter dihitung dengan menggunakan ARIMA untuk data non-seasonal adalah sebagai berikut:

a. Autoregressive Model

$\mathrm{Yt}=\mathrm{b}_{\mathrm{o}}+\mathrm{b}_{1} \mathrm{Y}_{\mathrm{t}-1}+\mathrm{b}_{2} \mathrm{Y}_{\mathrm{t}-2}+\ldots \mathrm{b}_{\mathrm{n}} \mathrm{Y}_{\mathrm{t}-\mathrm{n}}+\mathrm{et}_{\mathrm{t}}$

Notasi

$\mathrm{Yt}=$ Variabel dependen (net income)

$\mathrm{Y}_{\mathrm{t}-1,}, \mathrm{Y}_{\mathrm{t}-2,}, \mathrm{Y}_{\mathrm{t}-\mathrm{n}}=$ Variabel independen (variabel dengan lag tertentu)

$\mathrm{b}_{\mathrm{o}}, \mathrm{b}_{1}, \mathrm{~b}_{2}, \mathrm{~b}_{\mathrm{n}}=$ Koefisien regresi

$\mathrm{e}_{\mathrm{t}}=$ residual (error)

Jumlah koefisien regresi tersebut sering ditulis "p"

b. Differencing (degree of differencing)

Sebagai syarat untuk melakukan analisis dengan ARIMA adalah bahwa runtut waktu data yang ada adalah stasioner (suatu keadaan yang linier dan variance-nya tidak berubah). Oleh karena itu, apabila data yang ada nonstationary, maka data tersebut perlu diubah dengan melakukan differencing diantara data yang ada tersebut.

$\mathrm{Y}_{\mathrm{t}}=\mathrm{satu}$ rentetan data baru

$\mathrm{Y}_{\mathrm{t}}=$ satu rentetan data awal

$\mathrm{Y}_{\mathrm{t}-1}=$ satu rentetan data awal lag 1

Jika dengan melakukan differencing pertama, data belum menunjukkan stasioner, maka dilakukan differencing kedua dengan rumus sebagai berikut:

$\mathrm{Y}_{\mathrm{t}}^{\prime}=\mathrm{Y}_{\mathrm{t}}-\mathrm{Y}_{\mathrm{t}-1}$

Notasi:

$\mathrm{Y}_{\mathrm{t}}=$ satu rentetan data dengan differencing kedua

$\mathrm{Y}_{\mathrm{t}-1}=$ satu rentetan data baru dengan lag 1

Biasanya hal ini maksimal terjadi hanya sampai "second order differencing dan jumlah tingkat differencing tersebut ditulis dengan " $\mathrm{d}$ "

c. Moving average model

Ditulis dengan rumus: $\mathrm{Yt}=\mathrm{W}_{\mathrm{o}}+\mathrm{W}_{1} \mathrm{e}_{\mathrm{t}-1}-\mathrm{W}_{2} \mathrm{e}_{\mathrm{t}-2+} \mathrm{W}_{\mathrm{net}-\mathrm{n}}+\mathrm{e}_{\mathrm{t}}$ 
Notasi,

$\mathrm{Y}_{\mathrm{t}}=$ Variabel dependen

$\mathrm{W}_{1}, \mathrm{~W}_{1}, \mathrm{Wq}=$ koefisien

$\mathrm{e}_{\mathrm{t}}=$ error

et-1, et-2, et-q = nilai error lag 1,2, dst.

Biasanya koefisien (parameters) pada model ini dilambangkan dengan "q". Jadi jika keseluruhan tiga komponen di atas inilah yang kemudian disebut ARIMA (p,d,g) dan rumus-rumus di atas dapat digabung. Contoh ARIMA $(1,1,1)$.

$$
\mathrm{Yt}=\mathrm{b}_{0}+\mathrm{b}_{1} \mathrm{Y}_{\mathrm{t}-1}+\mathrm{e}_{\mathrm{t}}+\mathrm{W}_{1} \mathrm{e}_{\mathrm{t}-1}
$$

Langkah-langkah yang dilakukan dalam penerapan ARIMA dalam riset ini adalah:

Tahap pertama: identifikasi model; Pertama adalah menentukan apakah rentetan data tersebut stasioner atau tidak baik untuk laba. Jika tidak, maka perlu mengubah rentetan data tersebut menjadi stasioner melalui differencing, yaitu selisih antara data periode $t$ dengan data periode $t$ 1. Pengujian akar-akar unit atau ADF (Augmented Dickey-Fuller) dilakukan untuk mengetahui apakah data yang digunakan stasioner atau tidak.

Tahap kedua: Apabila rentatan laba tersebut stasioner, maka tentukanlah bentuk model yang akan digunakan. Langkah ini dicapai untuk disesuaikan dengan distribusi yang sesuai dengan bentuk model ARIMA. Selanjutnya menguji kelayakan model dengan mencari model yang terbaik. Setelah mengestimasi model tentatif selanjutnya mencari model terbaik. Menurut Kuncoro (2001) model terbaik setidaknya memiliki: (1) goodness of fit terbaik sebagaimana terlihat dari nilai $\mathrm{F}$ dan adjusted $\mathrm{R}^{2}$ yang tertinggi dan nilai statistik t yang signifikan; (2) RMSE (Root Mean Squares Error) minimal.

Tahap ketiga: Peramalan dengan model tersebut. Apabila model yang cocok telah ditemukan maka peramalan di masa yang datang dapat dilakukan. Oleh karena itu kita dapat membandingkan antara hasil peramalan dengan laba yang sesungguhnya dengan melakukan uji beda 2 mean (independent sample T-test) untuk membuktikan kemampuan laba dalam meramal laba masa depan. Apabila p-value lebih kecil dari alfa $5 \%$ maka hipotesis nol akan ditolak.

\section{Pengujian hipotesis kedua}

Pegujian hipotesis kedua dilakukan dengan tahapan seperti pengujian hipotesis pertama dengan data harga saham. Apabila model yang cocok telah ditemukan maka peramalan di masa yang datang dapat dilakukan. pengujian hipotesis dilakukan dengan membandingkan antara harga hasil peramalan dengan harga yang sesungguh-
nya.Untuk membandingkan antara harga hasil peramalan dengan yang sesungguhnya dengan melakukan uji beda 2 mean (independent sample T-test) untuk membuktikan kemampuan harga time series dalam meramal harga masa depan. Apabila p-value lebih kecil dari alfa 5\% maka hipotesis yang disampaikan dapat terdukung artinya terdapat kemampuan harga dalam memprediksi harga masa depan.

\section{Pengujian hipotesis ketiga}

Pengujian hipotesis ketiga dilakukan untuk membuktikan apakah laba dapat digunakan untuk memprediksi pola harga saham. Pengujian hipotesis ketiga diawali dengan menganalisis pola (pattern) pergerakan laba dan pergerakan harga saham. Pengujian ini untuk melihat apakah pola pergerakannya simetris atau tidak yang ditunjukkan dengan gambar grafik. Jika pola pergerakan laba dalam grafik simetris dengan pola pergerakan harga saham, pengujian selanjutnya dengan melihat comovement dari laba dan harga saham. Jika pola pergerakan antara laba dan harga saham ber-comovement, maka hipotesis ketiga terdukung, artinya laba dapat digunakan untuk memprediksi pola harga saham.

\section{Pengujian hipotesis keempat dan kelima}

Pengujian hipotesis keempat dilakukan seperti pengujian hipotesis pertama, dengan data arus kas. Pengujian hipotesis kelima dilakukan untuk membuktikan apakah arus kas dapat digunakan untuk memprediksi pola harga saham. Pengujian hipotesis kelima diawali dengan menganalisis pola (pattern) pergerakan arus kas dan pergerakan harga saham. Pengujian ini untuk melihat apakah pola pergerakannya simetris atau tidak yang ditunjukkan dengan gambar grafik. Jika pola pergerakan arus kas dalam grafik simetris dengan pola pergerakan harga saham, pengujian selanjutnya dengan melihat comovement dari arus kas dan harga saham. Jika pola pergerakan antara arus kas dan harga saham ber-comovement, maka hipotesis kelima terdukung, artinya arus kas dapat digunakan untuk memprediksi pola harga saham.

\section{HASIL PENELITIAN DAN PEMBAHASAN}

\section{Kemampuan prediksi laba time series dalam memprediksi laba masa depan.}

Berdasarkan tahapan analisis yaitu uji stasioneritas, pencarian model tentatif dan peramalan dengan model yang diperoleh suatu model peramalan sebagaimana ditunjukkan dalam Tabel 1. 
Tabel 1. Model Peramalan Laba

\begin{tabular}{|c|c|c|c|c|c|c|c|}
\hline COMPANY & MODEL & KONST. & $\mathrm{AR}(1)$ & $\mathrm{AR}(2)$ & $\mathrm{MA}(1)$ & MA (2) & Adjusted-R ${ }^{2}$ \\
\hline COMP1 & $\operatorname{ARIMA}(1,2,2)$ & 9745.933 & -0.6986 & & & -0.9795 & 0.688894 \\
\hline COMP2 & $\operatorname{ARIMA}(0,2,1)$ & -4053.585 & & & -2.5356 & & 0.864436 \\
\hline COMP3 & $\operatorname{ARIMA}(2,1,2)$ & 43263.28 & & -0.4055 & & 0.92637 & 0.792543 \\
\hline COMP4 & $\operatorname{ARIMA}(1,2,2)$ & -9957.005 & -0.6990 & & & -0.9112 & 0.868792 \\
\hline COMP5 & $\operatorname{ARIMA}(1,0,1)$ & 365120.8 & 1.31239 & & -2.0819 & & 0.914876 \\
\hline COMP6 & $\operatorname{ARIMA}(0,2,1)$ & 2012.190 & & & -0.9898 & & 0.511201 \\
\hline COMP7 & $\operatorname{ARIMA}(0,1,1)$ & 104063.2 & & & -0.9221 & & 0.194610 \\
\hline COMP8 & $\operatorname{ARIMA}(1,0,1)$ & -215993.1 & -0.1558 & & 0.8920 & & 0.158189 \\
\hline COMP9 & $\operatorname{ARIMA}(2,0,2)$ & 181834.1 & & -0.5276 & & 0.86495 & -0.05947 \\
\hline COMP10 & $\operatorname{ARIMA}(0,2,1)$ & 14077.33 & & & -2.6262 & & 0.877280 \\
\hline COMP11 & $\operatorname{ARIMA}(0,1,1)$ & 42454.71 & & & -0.8694 & & 0.262192 \\
\hline COMP12 & $\operatorname{ARIMA}(1,2,2)$ & 9371.889 & -1.0489 & & & -0.8514 & 0.662014 \\
\hline COMP13 & $\operatorname{ARIMA}(0,1,1)$ & 5664.012 & & & -09897 & & 0.489157 \\
\hline COMP14 & $\operatorname{ARIMA}(1,2,2)$ & -387077.5 & -0.4449 & & & -0.9799 & 0.841249 \\
\hline COMP15 & $\operatorname{ARIMA}(1,0,1)$ & 61257.90 & 0.71673 & & -0.9899 & & 0.293293 \\
\hline COMP16 & $\operatorname{ARIMA}(0,2,1)$ & -2754.709 & -2754.7 & & -2.8843 & & 0.884993 \\
\hline COMP17 & $\operatorname{ARIMA}(0,2,1)$ & -956.7747 & & & & -2.9143 & 0.905578 \\
\hline COMP18 & $\operatorname{ARIMA}(1,2,2)$ & -10492.24 & -0.4200 & & & -0.9799 & 0.88914 \\
\hline COMP19 & $\operatorname{ARIMA}(0,2,1)$ & -93757.64 & & & & -2.5603 & 0.87794 \\
\hline COMP20 & $\operatorname{ARIMA}(0,2,1)$ & -1149.17 & & & -2.5741 & & 0.860335 \\
\hline COMP21 & $\operatorname{ARIMA}(1,1,2)$ & 116408.2 & -0.6048 & & & -0.9799 & 0.898880 \\
\hline COMP22 & $\operatorname{ARIMA}(1,0,1)$ & 9243.966 & 1.75608 & & -2.6845 & & 0.986324 \\
\hline
\end{tabular}

Tabel 2. Uji beda dua rata-rata (independent samples test)

\begin{tabular}{|c|c|c|c|c|c|c|c|c|c|c|}
\hline & \multicolumn{2}{|c|}{$\begin{array}{c}\text { Levene's test for equality } \\
\text { of variance }\end{array}$} & \multicolumn{6}{|c|}{ t-test for equality of means } & \multicolumn{2}{|c|}{$\begin{array}{c}95 \% \text { confidence interval of } \\
\text { the difference }\end{array}$} \\
\hline & & $\mathrm{F}$ & Sig. & $\mathrm{T}$ & Df & $\begin{array}{c}\text { Sig. } \\
\text { (2-tailed) }\end{array}$ & $\begin{array}{c}\text { Mean } \\
\text { difference }\end{array}$ & $\begin{array}{l}\text { Std. Error } \\
\text { difference }\end{array}$ & Lower & upper \\
\hline \multirow[t]{2}{*}{ Laba } & $\begin{array}{l}\text { Equal variance } \\
\text { assumed }\end{array}$ & 0,09 & 0,76 & 0,062 & 410 & 0,95 & 830,8106 & 7733,583 & -147975 & 57636,9 \\
\hline & $\begin{array}{l}\text { Equal variance not } \\
\text { assumed }\end{array}$ & & & 0,062 & 407,48 & 0,95 & 830,8106 & 7350,908 & -147226 & 56887,4 \\
\hline
\end{tabular}

Model yang telah diperoleh selanjutnya digunakan untuk melakukan peramalan laba. Untuk menjawab hipotesis pertama kita akan meilhat dengan cara melakukan uji beda mean untuk nilai actual dengan nilai fitted-nya seluruh perusahaan sampel. Dari hasil uji beda rata-rata dua mean diperoleh hasil seperti pada Tabel 2.

Berdasarkan tabel tersebut menunjukkan bahwa nilai signikansi sebesar 0,95 berarti tidak signifikan. Artinya secara statistik tidak terdapat perbedaan yang signifikan antara laba sebenarnya dengan laba ramalan. Hal ini menunjukkan bahwa secara statistik hipotesis yang menyatakan bahwa terdapat kemampuan time series laba memprediksi laba terdukung. Hasil penelitian ini mendukung temuan Parawiyati (1996), Sunariyah (1996), Isgiyarta (1997), Parawiyati dan Baridwan (1998), Werdiningsih (2000), Madjid (2002), Kholidiyah (2002), Andayani et al. (2011), dan Junaidi (2011).

Kemampuan prediksi harga time series dalam memprediksi harga masa depan

Sebagaimana tahapan analisis pada bagian 4.1, pengujian prediksi harga saham dilakukan dengan langkah yang sama dengan 4.1, yaitu uji stasioneritas, pencarian model tentatif dan peramalan dengan model yang diperoleh. Berdasarkan tahapan analisis diperoleh suatu model peramalan harga sebagaimana ditunjukkan dalam Tabel 3.

Untuk menjawab hipotesis kedua kita akan melihat dengan cara melakukan uji beda mean untuk nilai actual dengan nilai fitted-nya seluruh perusahaan sampel. Dari hasil uji beda rata-rata dua mean diperoleh hasil seperti pada Tabel 4

Berdasarkan uji beda rata-rata diperoleh nilai sinifikansi 0,487 dengan alfa 0,05. Karena nilai signifikansi lebih besar dari alfa maka, hipotesis yang menyatakan bahwa terdapat kemampuan prediksi harga time series dalam memprediksi harga masa depan terdukung. Hasil penelitian ini selaras dengan penelitian Junaidi (2011) bahwa harga saham time series dapat digunakan untuk memprediksi harga saham masa depan.

\section{Kemampuan prediksi laba terhadap pola harga saham}

Untuk melihat kemampuan prediksi laba time series terhadap pola pergerakkan harga 
Tabel 3. Peramalan Harga

\begin{tabular}{|c|c|c|c|c|c|c|c|}
\hline COMPANY & MODEL & KONST. & $\mathrm{AR}(1)$ & $\mathrm{AR}(2)$ & MA(1) & MA(2) & Adjusted-R ${ }^{2}$ \\
\hline COMP1 & $\operatorname{ARIMA}(0,0,2)$ & 1302.444 & & & & $-0,929626$ & 0,171642 \\
\hline COMP2 & $\operatorname{ARIMA}(0,0,2)$ & 14999,23 & & & & 0,834602 & 0,138610 \\
\hline COMP3 & $\operatorname{ARIMA}(0,0,1)$ & 599,5133 & & & 0,950672 & & 0,408476 \\
\hline COMP4 & $\operatorname{ARIMA}(1,0,1)$ & 100,1504 & 0,262495 & & $-0,989949$ & & 0,971817 \\
\hline COMP5 & $\operatorname{ARIMA}(2,0,2)$ & 12307,28 & & $-0,782374$ & & 0,925718 & 0,714372 \\
\hline COMP6 & $\operatorname{ARIMA}(0,0,1)$ & 1120,083 & & & 0,968855 & & 0,49765 \\
\hline COMP7 & $\operatorname{ARIMA}(2,0,0)$ & 417,6454 & & $-0,469199$ & & & 0,369202 \\
\hline COMP8 & $\operatorname{ARIMA}(1,0,1)$ & 1029,143 & 0,680029 & & $-2,323218$ & & 0,744273 \\
\hline COMP9 & $\operatorname{ARIMA}(2,1,0)$ & $-54,31952$ & & $-0,541569$ & & & 0,654855 \\
\hline COMP10 & $\operatorname{ARIMA}(1,1,1)$ & $-42,66785$ & 0,329278 & & $-2,561992$ & & 0,849885 \\
\hline COMP11 & $\operatorname{ARIMA}(1,2,2)$ & 29,73027 & $-0,801287$ & & $-0,979872$ & & 0,690267 \\
\hline COMP12 & $\operatorname{ARIMA}(1,0,0)$ & 160,1940 & 0,521440 & & & & 0,525323 \\
\hline COMP13 & $\operatorname{ARIMA}(0,1,1)$ & $-67,93719$ & & & 0,869975 & & 0,12027 \\
\hline COMP14 & $\operatorname{ARIMA}(1,0,1)$ & 179,3149 & 0,520792 & & $-2,513236$ & & 0,967016 \\
\hline COMP15 & $\operatorname{ARIMA}(0,1,1)$ & 72,09621 & & & $-2,377075$ & & 0,830357 \\
\hline COMP16 & $\operatorname{ARIMA}(1,0,1)$ & 304,0944 & 0,725608 & & $-0,989721$ & & 0,367391 \\
\hline COMP17 & $\operatorname{ARIMA}(1,0,2)$ & 405,1001 & $-5,568994$ & & & $-0,979997$ & 0,970755 \\
\hline COMP18 & $\operatorname{ARIMA}(1,0,2)$ & 492,7525 & 0,499637 & & & $-0,979995$ & 0,989937 \\
\hline COMP19 & $\operatorname{ARIMA}(1,1,1)$ & $-40,02284$ & 0,206039 & & $-2,562598$ & & 0,923598 \\
\hline COMP20 & $\operatorname{ARIMA}(1,0,0)$ & 68,91437 & 0,485222 & & & & 0,844647 \\
\hline COMP21 & $\operatorname{ARIMA}(0,0,1)$ & 575,4214 & & & 0,989862 & & 0,514044 \\
\hline COMP22 & $\operatorname{ARIMA}(0,1,1)$ & $-158,4099$ & & & $-0,989879$ & & 0,581598 \\
\hline
\end{tabular}

Tabel 4. Uji beda dua rata-rata (independent samples test)

\begin{tabular}{|c|c|c|c|c|c|c|c|c|c|c|}
\hline & \multicolumn{2}{|c|}{$\begin{array}{l}\text { Levene's test for equality of } \\
\text { variance }\end{array}$} & \multicolumn{6}{|c|}{ t-test for equality of means } & \multicolumn{2}{|c|}{$\begin{array}{l}95 \% \text { confidence interval } \\
\text { of the difference }\end{array}$} \\
\hline & & $\mathrm{F}$ & Sig. & $\mathrm{T}$ & Df & $\begin{array}{c}\text { Sig. } \\
\text { (2-tailed) }\end{array}$ & $\begin{array}{c}\text { Mean } \\
\text { difference }\end{array}$ & $\begin{array}{l}\text { Std. Error } \\
\text { difference }\end{array}$ & Lower & upper \\
\hline \multirow[t]{2}{*}{ Laba } & $\begin{array}{l}\text { Equal variance } \\
\text { assumed }\end{array}$ & 1,608 & 0,205 & 0,695 & 542 & 0,487 & 215,5927 & 810,27325 & $-393,893$ & 25,07815 \\
\hline & $\begin{array}{l}\text { Equal variance not } \\
\text { assumed }\end{array}$ & & & 0,680 & 463,47 & 0,497 & 215,5927 & 817,01529 & $-407,373$ & 38,55811 \\
\hline
\end{tabular}

saham kita akan melihat korelasi seluruh data laba perusahaan dengan harga saham. Jika pola pergerakan laba sama dengan pola pergerakkan harga maka dapat dikatakan bahwa kedua data tersebut memiliki hubungan yang signifikan sebagaimana ditunjukkan dengan nilai korelasi antara series laba dengan series harga saham.

Jika nilai korelasi positip signifikan dapat dikatakan bahwa time series laba dapat digunakan untuk memprediksi harga saham. Berdasarkan tabel diatas nilai korelasi sebesar 0,167 dengan nilai signifikansi 0,007. Berdasarkan analisis statistik menunjukkan nilai signifikansi 0,007 dibawah alfa 0,05. Oleh karena itu dapat dikatakan bahwa secara statistik hipotesis yang menyatakan bahwa terdapat kemampuan laba time series dalam memprediksi pola harga saham terdukung. Hasil penelitian ini mendukung penelitian Junaidi (2011).

\section{Kemampuan prediksi arus kas time series dalam memprediksi arus kas masa depan.}

Untuk menguji kemampuan prediksi arus kas time series dalam memprediksi arus kas masa depan pada bagian ini dapat dilakukan menurut langkah pengujian bagian 4.1. Berdasarkan tahapan analisis diperoleh suatu model peramalan sebagaimana ditunjukkan dalam Tabel 5.

Model yang telah diperoleh selanjutnya digunakan untuk melakukan peramalan arus kas. Untuk menjawab hipotesis keempat kita akan melihat dengan cara melakukan uji beda mean untuk nilai actual dengan nilai fitted-nya seluruh perusahaan sampel. Dari hasil uji beda rata-rata dua mean diperoleh hasil seperti tabel 6 .

Hasil uji beda menunjukkan tingkat signifikansi adalah 0,873 berarti tidak signifikan. Hal ini berarti hipotesis yang disampaikan bahwa terdapat kemampuan time series arus kas memprediksi arus kas masa depan dapat terdukung. Temuan ini mendukung penelitian Bowen et al . (1986) dan Parawiyati dan Baridwan (1998).

\section{Kemampuan prediksi arus kas terhadap pola harga saham}

Untuk melihat kemampuan prediksi arus kas time series terhadap pola pergerakkan harga saham kita akan melihat korelasi seluruh data 
Tabel 5. Model Peramalan Arus Kas

\begin{tabular}{|c|c|c|c|c|c|c|c|}
\hline COMPANY & MODEL & KONST. & $\mathrm{AR}(1)$ & $\mathrm{AR}(2)$ & MA(1) & MA(2) & Adjusted-R ${ }^{2}$ \\
\hline COMP1 & $\operatorname{ARIMA}(1,0,1)$ & $1,19 \mathrm{E}+09$ & 0,658200 & & $-0,9897$ & & 0,270364 \\
\hline COMP2 & $\operatorname{ARIMA}(0,1,1)$ & 25979649 & & & $-0,9899$ & & 0,998122 \\
\hline COMP3 & ARIMA(2,2,1) & $-1,30 \mathrm{E}+09$ & & $-0,7107$ & $-0,9899$ & & 0,769303 \\
\hline COMP4 & $\operatorname{ARIMA}(1,1,2)$ & $-2,34 \mathrm{E}+09$ & $-0,71808$ & & & $-6,8582$ & 0,978823 \\
\hline COMP5 & $\operatorname{ARIMA}(1,2,0)$ & $7,61 \mathrm{E}+09$ & $-0,76006$ & & & & 0,544211 \\
\hline COMP6 & $\operatorname{ARIMA}(1,0,1)$ & -2044585 & 0,735484 & & $-0,98967$ & & 0,536350 \\
\hline COMP7 & $\operatorname{ARIMA}(0,1,1)$ & $-9,26 \mathrm{E}+09$ & & & $-0,9895$ & & 0,486128 \\
\hline COMP8 & $\operatorname{ARIMA}(2,1,2)$ & $-1,26 \mathrm{E}+09$ & & $-0,36971$ & & 2,4122 & 0,886184 \\
\hline COMP9 & $\operatorname{ARIMA}(0,0,2)$ & $2,58 \mathrm{E}+10$ & & & & $-0,8726$ & 0,409488 \\
\hline COMP10 & $\operatorname{ARIMA}(1,1,2)$ & $1,27 \mathrm{E}+09$ & $-0,73184$ & & & $-0,9799$ & 0,564690 \\
\hline COMP11 & $\operatorname{ARIMA}(0,2,2)$ & $-1,16 \mathrm{E}+10$ & & & & $-0,980$ & 0,814279 \\
\hline COMP12 & $\operatorname{ARIMA}(0,0,2)$ & $4,15 \mathrm{E}+09$ & & & & 0,93158 & 0,735015 \\
\hline COMP13 & $\operatorname{ARIMA}(0,0,2)$ & $2,33 \mathrm{E}+09$ & & & & 0,9385 & 0,746383 \\
\hline COMP14 & $\operatorname{ARIMA}(1,2,2)$ & $-4,56 \mathrm{E}+09$ & $-0,68332$ & & & $-0,98$ & 0,694898 \\
\hline COMP15 & $\operatorname{ARIMA}(1,1,2)$ & $2,11 \mathrm{E}+09$ & $-0,82789$ & & & $-0,9799$ & 0,651780 \\
\hline COMP16 & $\operatorname{ARIMA}(1,1,2)$ & -20802338 & $-0,838933$ & & & $-0,979785$ & 0,635361 \\
\hline COMP17 & $\operatorname{ARIMA}(1,1,2)$ & $-5,20 \mathrm{E}+09$ & $-0,690656$ & & & $-0,979458$ & 0,763598 \\
\hline COMP18 & $\operatorname{ARIMA}(2,0,2)$ & $2,27 \mathrm{E}+08$ & & 0,017228 & & 2,188483 & 0,995381 \\
\hline COMP19 & $\operatorname{ARIMA}(1,1,2)$ & $-5,42 \mathrm{E}+08$ & $-0,656211$ & & & $-0,884427$ & 0,371667 \\
\hline COMP20 & $\operatorname{ARIMA}(0,1,1)$ & $-3,22 \mathrm{E}+09$ & & & $-0,989436$ & & 0,544668 \\
\hline COMP21 & $\operatorname{ARIMA}(1,2,2)$ & $1,32 \mathrm{E}+08$ & $-0,498928$ & & & $-0,97999$ & 0,755118 \\
\hline COMP22 & $\operatorname{ARIMA}(1,2,2)$ & $1,08 \mathrm{E}+10$ & $-0,467214$ & & & $-0,94183$ & 0,946558 \\
\hline
\end{tabular}

Tabel 6. Uji beda dua rata-rata (independent samples test)

\begin{tabular}{|c|c|c|c|c|c|c|c|c|c|c|}
\hline & \multicolumn{2}{|c|}{$\begin{array}{l}\text { Levene's test for equality of } \\
\text { variance }\end{array}$} & \multicolumn{6}{|c|}{ t-test for equality of means } & \multicolumn{2}{|c|}{$\begin{array}{l}95 \% \text { confidence interval of } \\
\text { the difference }\end{array}$} \\
\hline & & $\mathrm{F}$ & Sig. & $\mathrm{T}$ & Df & $\begin{array}{c}\text { Sig. } \\
\text { (2-tailed) }\end{array}$ & $\begin{array}{c}\text { Mean } \\
\text { difference }\end{array}$ & $\begin{array}{l}\text { Std. Error } \\
\text { difference }\end{array}$ & Lower & upper \\
\hline \multirow[t]{2}{*}{ Laba } & $\begin{array}{l}\text { Equal variance } \\
\text { assumed }\end{array}$ & 0,056 & 0,813 & $-0,16$ & 452 & 0,873 & $-2,22 \mathrm{E}+09$ & $1,39 \mathrm{E}+10$ & $-3,0 \mathrm{E}+10$ & $2,5 \mathrm{E}+10$ \\
\hline & $\begin{array}{l}\text { Equal variance not } \\
\text { assumed }\end{array}$ & & & $-0,16$ & 451,9 & 0,872 & $-2,22 \mathrm{E}+09$ & $1,39 \mathrm{E}+10$ & $-2,9 \mathrm{E}+10$ & $2,5 \mathrm{E}+10$ \\
\hline
\end{tabular}

arus kas perusahaan dengan harga saham. Jika pola pergerakan arus kas sama dengan pola pergerakkan harga maka dapat dikatakan bahwa kedua data tersebut memiliki hubungan yang signifikan sebagaimana ditunjukkan dengan nilai korelasinya Jika nilai korelasi signifikan dapat dikatakan bahwa time series arus kas dapat digunakan untuk memprediksi harga saham.

Berdasarkan analisis statistik menunjukkan nilai korelasi sebesar 0,018 dan nilai signifikansi 0,783 lebih besar dari alfa 0,05. Oleh karena itu dapat dikatakan bahwa secara statistik hipotesis kelima yang menyatakan bahwa terdapat kemampuan arus kas time series dalam memprediksi pola harga saham tidak dapat terdukung.

\section{KESIMPULAN DAN SARAN}

Penelitian ini bertujuan untuk membuktikan secara empiris tentang kemampuan laba dalam memprediksi laba masa depan dan patern harga saham dan kemampuan arus kas dalam memprediksi arus kas masa depan dan pola harga saham. Sebanyak 22 sampel diperoleh berdasarkan kriteria tertentu. Setelah dilakukan analisis statistik diperoleh model yang fit untuk digunakan dalam peramalan laba, peramalan arus kas dan peramalan pola harga saham. Penelitian ini mengungkapkan lima hipotesis.

Secara statistik hipotesis pertama yang menyatakan bahwa terdapat kemampuan time series laba memprediksi laba terdukung. Pengujian hipotesis dua berdasarkan uji beda rata-rata diperoleh nilai sinifikansi 0,487 dengan alfa 0,05. Karena nilai signifikansi lebih besar dari alfa maka, hipotesis yang menyatakan bahwa terdapat kemampuan prediksi harga time series dalam memprediksi harga masa depan terdukung. Untuk menguji hipotesis ketiga kita melihat korelasi seluruh data laba perusahaan dengan harga saham. Jika nilai korelasi positip signifikan dapat dikatakan bahwa time series laba dapat digunakan untuk memprediksi harga saham. Berdasarkan analisis statistik menunjukkan nilai signifikansi 0,007 dibawah alfa 0,05 . Oleh karena itu dapat dikatakan bahwa secara statistik hipotesis yang menyatakan bahwa 
terdapat kemampuan laba time series dalam memprediksi pola harga saham terdukung.

Hipotesis keempat menunjukkan bahwa terdapat kemampuan prediksi arus kas time series dalam memprediksi arus kas masa depan. Hasil uji beda menunjukkan tingkat signifikansi adalah 0,873 berarti tidak signifikan. Hal ini berarti hipotesis yang disampaikan bahwa terdapat kemampuan time series arus kas memprediksi arus kas masa depan dapat terdukung.

Hipotesis kelima menyatakan bahwa terdapat kemampuan prediksi arus kas terhadap pola harga saham. Jika pola pergerakan arus kas sama dengan pola pergerakkan harga maka dapat dikatakan bahwa kedua data tersebut memiliki hubungan yang signifikan sebagaimana ditunjukkan dengan nilai korelasinya Jika nilai korelasi signifikan dapat dikatakan bahwa time series arus kas dapat digunakan untuk memprediksi harga saham. Berdasarkan analisis statistik menunjukkan nilai korelasi sebesar 0,018 dan nilai signifikansi 0,783 lebih besar dari alfa 0,05. Oleh karena itu dapat dikatakan bahwa secara statistik hipotesis kelima yang menyatakan bahwa terdapat kemampuan arus kas time series dalam memprediksi pola harga saham tidak dapat terdukung.

\section{Saran}

Penelitian ini menguji kemampuan time series laba dalam memprediksi laba masa depan dan pola harga saham. Selanjutnya penelitian ini menguji kemampuan time series arus kas dalam memprediksi laba masa depan dan pola harga saham. Hasil yang diperoleh mungkin dipengaruhi oleh pengambilan sampel yang purposive. Oleh karena itu penelitian selanjutnya dapat dilakukan dengan memperluas sampel penelitian. Riset ini juga belum mempertimbangkan faktor-faktor lain misalnya pengaruh perataan laba maupun informasi keuangan lain. Oleh karena itu penelitian berikutnya diharapkan dapat mempertimbangkan faktor-faktor yang diduga dapat mempengaruhi memprediksi laba, arus kas maupun pola harga saham.

\section{DAFTAR PUSTAKA}

Andayani, W., Junaidi, and Nurdiono. (2011), Annual earnings analysis with ARIMA for future earnings prediction, Journal of Modern Accounting and Auditing, 7(6), 645-651.

Ball, R. and Brown, P. (1968), An Empirical Evaluation of Accounting Income Numbers, Journal of Accounting Research, 159-178.
----- and R. Watts (1972), Some Time Series Properties of Accounting Income, Journal of Finance, 663-682.

Baridwan, Z. (2004), Intermediate Accounting, Edisi 8, BPFE, Yogyakarta.

------ (1997), Analisis Tambahan Informasi Laporan Arus Kas, Jurnal Ekonomi dan Bisnis Indonesia, 12, 113.

Victor, B, L. and Stober, T. L. (1989), The Nature and Amount of Information in Cash Flows and Accrual, The Accounting Review, 624-652.

Bowen, R. M., Burgstahler, D., and Daley, L.A. (1986), The Evidence on The Relationship Between Earnings and Various Measures of Cash Flow from Operation, The Accounting Review (LXI), 4, 713.

Beaver, W. H. (1970), The Time Series Behavior of Earnings, Supplement to Journal of Accounting Research, page 62-69.

Brown, L. D. (1993), Earnings Forecast Research: Its Implications for Capital Market Research, International and Business Research, 14, Spring, 113-124.

Fairfield, P. M., Sweeney, R. J., and Yohn, T. L. (1996), Accounting Classification and The Predictive Content of Earnings, The Accounting Review, 71(3), 337-355.

Febriyanti, G. A. (2004), Perbandingan Keakuratan Model Laba Permanen, Transitori dan Laba Agregat dalam Memprediksi Laba Masa Depan, Proceeding, SNA VII, Bali.

Finger, C. A. (1994), The Ability of Earnings to Predict Future Cash Flow, Journal of Accounting Research, 32(32), Autumn, 210-223.

Foster, George (1986), Financial Statement Analysis, Second Edition, Prentice-Hall International. -- (1977a), Quarterly Accounting Data: Timeseries Properties and Predictive-Ability Result, Accounting Review, page 1-21.

Hendriksen, E. S. and van Breda (1991), Accounting Theory, Fifth Edition, Irwin United State of America.

Hermawan, A. dan Hadyansah, N. (2002), Analisa Pengaruh Format Metode Langsung Dalam Laporan Arus Kas Terhadap Return Saham, Proceeding, Simposium Nasional Akuntansi, September, 102-110.

Ismail, B. E. and Kim, M. A (1989). On The Association of Cash Flows Variables with Market Risk: Further Evidence, The Accounting Review, January, 125-136.

Ikatan Akuntan Indonesia (2009), Standar Akuntansi Keuangan, Jakarta, Devisi Penerbitan IAI.

Isgiyarta, J. (1997), Klasifikasi Akuntansi dan Kemampuan Prediksi Laba, Tesis S2, Tidak Dipublikasikan, Universitas Gadjah Mada. 
Junaidi (2011), Earnings Performance in Predicting Future Earnings And Stock Price Pattern. Journal of Economics, Business, \& Accountancy (Ventura), 14(2), 107-112.

Kieso, D. E., Weygandt, J. J., and Warfield, T. D. (2011), Intermediate Accounting, volume 1, John Willey \& Son, USA.

Kholidiah (2002), Perbandingan Keakuratan Metode Naïve, Regresi Sederhana \& Box-Jenkins, Tesis S2, Tidak Dipublikasikan, Universitas Gadjah Mada, Yogyakarta.

Kusuma, Poppy, D. I. (2003), Nilai Tambah Kandungan Informasi Laba dan Arus Kas Operasi, Proceeding, Simposium Nasional Akuntansi (SNA) VI, Surabaya, 304-313.

Kuncoro, Mudrajad (2001), Metode Kuantitatif: Teori dan Aplikasi untuk Bisnis dan Ekono$m i$, Edisi pertama, UPP AMP YKPN, Yogyakarta.

Lipe R. C., (1986), The Information Contained in The Components of Earnings, Journal of Accounting Research, 24, Supplement, 37-64.

Parawiyati, dan Baridwan, Z. (1998), Kemampuan Laba dan Arus Kas dalam Memprediksi Laba dan Arus Kas Perusahaan Go Publik di Indonesia, Jurnal Riset Akuntansi Indonesia, 1-11.
Rayburn, J. (1986). The Association of Operating Cash Flow and Accrual with Security Returns, Journal of Accounting Research (Supplement), 112-133

Sugiri, S. (2003), Kemampuan Laba Rincian untuk Memprediksi Arus Kas, Desertasi, Tidak Dipublikasikan, Universitas Gadjah Mada, Yogyakarta.

Supriyadi (1999), The Perdictive Ability of Earnings Versus Cash Flow Data to Predict Future Cash Flows: A Firm Specific Analysis, Gadjah Mada International Journal of Business, 1(2), 113-132.

Sunariyah (1996), Ketepatan Ramalan Laba di Prospektus Pada Awal Penawaraan Umum di Pasar Modal Indonesia, Tesis S2, Tidak Dipublikasikan, Universitas Gadjah Mada, Yogyakarta.

Utami, C. D. (1999), Muatan Informasi Arus Kas dari Aktivitas Operasi, Investasi, dan Pendanaan, Jurnal Bisnis dan Akuntansi, 1, 15-27.

Sri, W. (2000), Pengaruh Klasifikasi Komponen Laba terhadap Kemampuan Prediksi Laba, Tesis S2, Universitas Gadjah Mada, Yogyakarta. 